\title{
Brefeldin-A: an Antiproliferative Metabolite of the Fungus Curvularia trifolii Collected from the Veracruz Coral Reef System, Mexico
}

\author{
César Espinoza, ${ }^{1}$ Alan Couttolenc, ${ }^{2}$ José J. Fernández, ${ }^{3}$ Manuel Norte, ${ }^{3}$ Gabriela B. Plata, ${ }^{3}$ José M. Padrón, ${ }^{3}$ \\ Alla Shnyreva, ${ }^{4}$ Ángel Trigos ${ }^{1,2 *}$ \\ 1 Laboratorio de Alta Tecnología de Xalapa, Universidad Veracruzana, Calle Médicos No. 5, Col. Unidad del Bosque, 91010 , \\ Xalapa-Veracruz, México. \\ 2 Doctorado en Ciencias Biomédicas, Universidad Veracruzana, Avenida Dr. Luis Castelazo Ayala s/n, Xalapa-Veracruz, México. \\ 3 Instituto Universitario de Bio-Orgánica “Antonio González” (IUBO-AG), Universidad de La Laguna, Avenida Astrofísico \\ Francisco Sánchez 2, 38206 La Laguna, España. \\ 4 Department of Mycology and Algology, Faculty of Biology, Moscow Lomonosov State University, Moscow, Russia.
}

* Author to whom correspondence should be addressed. E-mail: atrigos@uv.mx.

Phone and fax: 522288140231 and 522288404255

Received December 14 ${ }^{\text {th }}, 2015$; Accepted March 16 ${ }^{\text {th }}, 2016$.

\begin{abstract}
In this paper the isolation and structure analysis of three sterols and brefeldin-A from the mycelial extract of the liquid fermentation of fungus Curvularia trifolii isolated from the marine sponge Amphimedon compressa collected from the Coral Reef System of Veracruz is reported. This is the first report on the production of brefeldin-A by the fungus $C$. trifolii. The results on isolation biological activity support the importance of the conservation of the Mexican ecosystems of coral reefs as a source of microorganisms with a pharmaceutical potential.

Key words: Antiproliferative activity; brefeldin-A; Curvularia trifolii; Amphimedon compressa.
\end{abstract}

\section{Introduction}

Fungi have been shown to have great potential as a source of bioactive metabolites. This is supported by the variety of reported secondary metabolites secreted by fungi. For this reason, terrestrial fungi have been widely studied. Nevertheless, marine fungi have received attention only to a limited extent [1]. Among these organisms, the genus Curvularia (Ascomycota) is a rich source for a wide range of bioactive compounds [2]. In particular, the estrogen agonist zearalenone [3]; macrolides, such as radicol and curvularin derivatives, with antitumor activity [4]; the antibiotic lunatin [5]; antifungal benzopyranes [6]; and apralactone A with a cytotoxic activity [7]. In this paper, the isolation and identification of bioactive metabolites from a culture of Curvularia trifolii isolated from the marine sponge Amphimedon compressa collected in the "Sistema Arrecifal Veracruzano" (SAV) are presented.

\section{Results and Discussion}

Sponge samples of Amphimedon compressa were collected in the shallow waters of the SAV. The samples were used to isolate
Resumen. Se reporta el aislamiento e identificación de tres esteroles y la brefeldina A a partir del extracto micelial de la fermentación líquida del hongo Curvularia trifolii aislado de la esponja marina Amphimedon compressa originaria del Sistema Arrecifal Veracruzano. Este es el primer reporte de la producción de brefeldina A por el hongo C. trifolii. Los resultados del aislamiento y la evaluación apoyan la importancia de la conservación de ecosistemas mexicanos de arrecifes de coral como fuente de microorganismos con potencial farmacéutico.

Palabras clave: Actividad antiproliferativa; brefeldina A; Curvularia trifolii; Amphimedon compressa.

preferentially the naturally occurring fungus by means of chloramphenicol addition to the culture medium [8]. Morphological and phylogenetic (rDNA-ITS region sequence) analysis of the obtained mycelium confirmed the isolated strain as Curvularia trifolii. Next, C. trifolii was cultured extensively in order to obtain enough mass for further processing. The lyophilized remains of C. trifolii was extracted with $\mathrm{MeOH}: \mathrm{CHCl}_{3}(1: 1)$ and the solvent removed to yield a residue that was submitted for chromatographic separation in hexane:ethyl acetate mixtures (in order of increasing strength). Thin layer chromatography (TLC) was used for monitorization of the isolated compounds. Fractions containing single spot on TLC were concentrated and submitted to evaluation of their antiproliferative activity against a representative panel of human solid tumor cell lines. In this manner, the bioactivity guided fractionation allowed us to isolate compounds 1-4 (Fig. 1) from the liquid fermentation of the fungus $C$. trifolii. All the compounds were identified by comparison of their ${ }^{1} \mathrm{H}$ and ${ }^{13} \mathrm{C}$ NMR spectra with data previously reported in the literature. The resulting products were disclosed as ergosterol (1) [9], ergosterol peroxide (2) [9], cerevisterol (3) [10] and brefeldin-A (4) [11]. The fraction which presented higher values of antiproliferative activity (A549, SW1573, 
HeLa, HBL-100, T-47D, and WiDr with $\mathrm{GI}_{50} 1.2,1.4,0.69,1.4$, 1.0 , and $0.46 \mu \mathrm{g} / \mathrm{mL}$, respectively) corresponded to brefeldin $\mathrm{A}(4)$.

In this research the production of antiproliferative compounds by the fungus $C$. trifolii isolated from marine environment was studied. Although the isolated compounds are already known, this is the first report of the production of brefeldin-A by this particular Curvularia species. Additionally, the antiproliferative effect of the fraction from which $\mathbf{4}$ was isolated was demonstrated against five cancer cell lines, some of the cell lines being different from those already reported $[12,13]$. Finally, these results support the importance of the conservation of the Mexican ecosystems of coral reefs as a source of microorganisms with a pharmaceutical potential. Thus, we consider that further studies are needed to prove the value of this research that aimed at searching new bioactive compounds.

\section{General Experimental Procedures}

Melting points were determined using a Fisher Jones melting point apparatus and are uncorrected. 1D and 2D NMR spectra of pure compounds were recorded on a Varian Gemini 2000 operating at $300 \mathrm{MHz}$ for ${ }^{1} \mathrm{H}$ and $75 \mathrm{MHz}$ for ${ }^{13} \mathrm{C}$ and on a Bruker DMX500, operating at $600 \mathrm{MHz}$ for ${ }^{1} \mathrm{H}$ and $100 \mathrm{MHz}$ for ${ }^{13} \mathrm{C}$ in $\mathrm{CDCl}_{3}$ and $\mathrm{CD}_{3} \mathrm{OD}$; tetramethylsilane (TMS) was used as an internal standard. The chemical shifts were recorded in ppm $(\delta)$ and coupling constants $(J)$ in $\mathrm{Hz}$.

\section{Specimen collection}

The sponge samples were collected in the "Blancas" reef, part of the SAV during the period from June to October 2011, by diving in shallow water (1-3 m) and cutting little pieces of the biological material. Collected sponge samples were placed in sterile tubes with seawater, refrigerated and transported to the laboratory. The sponge samples were rinsed with sterile sea water three times, and then the surface of the tissue was disinfected with $70 \%$ ethanol. The tissue was cut into small pieces (approx. $1 \mathrm{~cm}^{2}$ ), then three pieces of each sample were homogenized in a tube with $20 \mathrm{~mL}$ of sterile sea water. Three dilutions were made from the homogenized tissue with sterile sea water $(1: 10$, $1: 100,1: 1000$ ). For fungal cultivation, $1 \mathrm{~mL}$ of each dilution was plated in duplicate onto potato dextrose agar, PDA (200 g potato infusion, $20 \mathrm{~g}$ dextrose, $15 \mathrm{~g}$ agar per liter of $50 \%$ sea water) using marine agar plates (Difco Marine agar 2216) supplied with chloramphenicol $(0.2 \mathrm{~g} / \mathrm{L}$ each). Plates were incubated at $25 \pm 2{ }^{\circ} \mathrm{C}$ until they showed mycelium development [14].

\section{Strain identification}

Identification of the fungus Curvularia trifolii (Kauffman) Boedijn (Pleosporaceae) was carried out by observation in slides of reproductive structures on PDA culture after 7-day incubation at $25 \pm 2{ }^{\circ} \mathrm{C}$. The slides were observed by optic
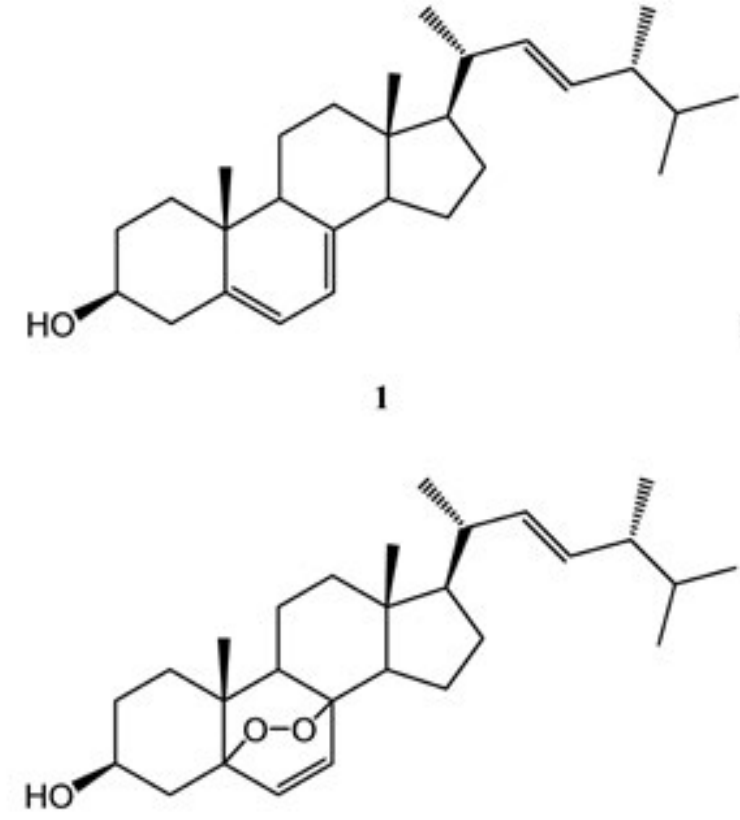

2
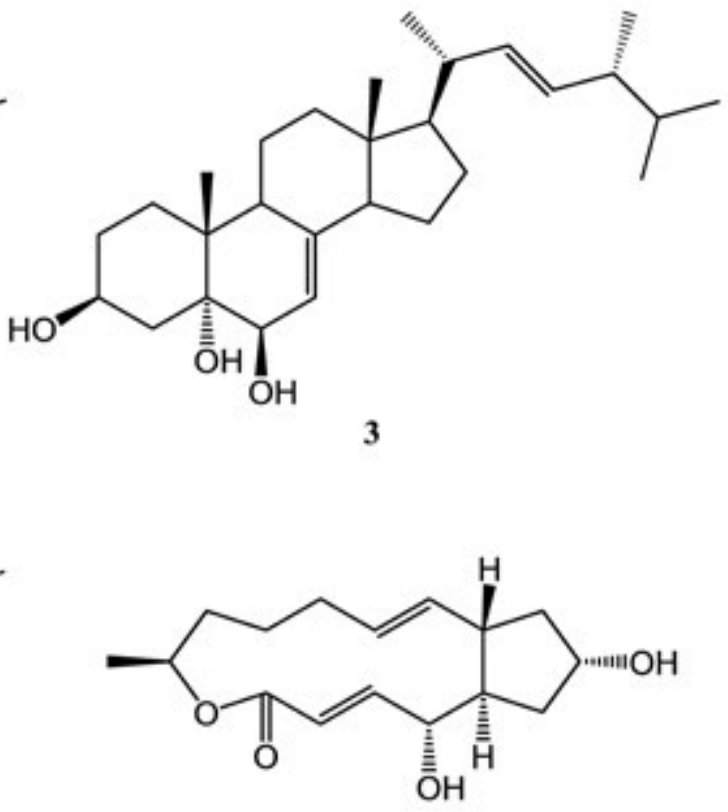

4

Fig. 1. Antiproliferative metabolites obtained from the mycelium of Curvularia trifolii isolated from the marine sponge Amphimedon compressa collected in the "Sistema Arrecifal Veracruzano". 
microscopy (Carl Zeiss Microscopy GmbH, Jena, Germany) employing lactophenol. The reproductive morphological characteristics were compared with taxonomic keys according to reports in the literature $[15,16]$. To corroborate the identification, a molecular study was performed using nuclear rDNA-ITS region sequence data. The obtained sequence was compared against nucleotide entries in the NCBI GenBank (http://www. ncbi.nlm.nih.gov/) by using the search tool Blastn to confirm species identity [8]. Finally, the strain was deposited in the strain collection of the Laboratorio de Alta Tecnología de Xalapa (accession number LAEE 03).

\section{Cell culture and plating}

Human solid tumor cell lines A549, SW1573, HeLa, HBL-100, T47D, and WiDr were maintained in a $25 \mathrm{~cm}^{2}$ culture flask in RPMI 1640 medium supplemented with 5\% heat inactivated fetal bovine serum, $2 \mu \mathrm{M}$ L-glutamine, 100 units penicillin $\mathrm{G}$ and $0.1 \mathrm{mg}$ per $\mathrm{mL}$ of streptomycin at $37{ }^{\circ} \mathrm{C}, 5 \% \mathrm{CO}_{2}, 95 \%$ humidified air incubator. Exponentially growing cells were trypsinized and re-suspended in a fresh medium. Single cell suspensions were subsequently counted using an automated cell counter (Orflo Moxi Z). Subsequently, counting dilutions were made to give the appropriate cell densities for inoculation onto 96-well microtiter plates. Cells were inoculated in a volume of $100 \mu \mathrm{L}$ per well at densities of 10,000 cells per well (for the cell lines A549, SW1573, HeLa, and HBL-100), 15,000 cells per well (for the cell line T47D), and 20,000 cells per well (for the cell line WiDr) based on doubling replicas.

\section{Antiproliferative activity}

Antiproliferative activity against human solid tumor cell lines mentioned above was screened using a sulforhodamine B assay (SRB) [17]. Dry pure fractions were initially dissolved in DMSO at 400 times to the desired final maximum test concentration. Control cells were exposed to an equivalent concentration of DMSO $(0.25 \% \mathrm{v} / \mathrm{v}$, negative control). Each fraction was tested at three different tenfold dilutions at a maximum concentration of $250 \mu \mathrm{g} / \mathrm{mL}$. The drug treatment was started $24 \mathrm{~h}$ after plating and incubation times were seen to be $48 \mathrm{~h}$, after that time the cells were precipitated with $25 \mu \mathrm{L}$ ice-cold TCA $(50 \% \mathrm{w} / \mathrm{v})$ and fixed for $60 \mathrm{~min}$ at $4{ }^{\circ} \mathrm{C}$. The SRB assay was then performed. The optical density (OD) of each well was measured at $492 \mathrm{~nm}$. The percentage growth was calculated at each level of the drug concentration based on the difference in OD at start and end points of drug exposure. Values were corrected for background OD of the control wells containing only the medium. The results obtained were expressed as the concentration of drug to cause $50 \%$ reduction in proliferation of cancer cells $\left(\mathrm{GI}_{50}\right)$.

\section{Fungal culture}

C. trifolii was cultured and maintained in marine Difco agar plates at a constant temperature $25 \pm 2{ }^{\circ} \mathrm{C}$. Subsequently, mycelium agar blocks $(1.0 \mathrm{~cm}$ in diameter each) were taken from 7-day cultured fungal plates and transferred aseptically to three $500 \mathrm{~mL}$ Erlenmeyer flasks with $100 \mathrm{~mL}$ culture medium composed of yeast extract $(4 \mathrm{~g} / \mathrm{L})$, soluble starch $(10 \mathrm{~g} / \mathrm{L})$, peptone $(2 \mathrm{~g} / \mathrm{L})$ and sea water $(75 \%)$. The flasks were incubated in continuous agitation of $125 \mathrm{rpm}$ at $25 \pm 2{ }^{\circ} \mathrm{C}$ for 7 days. In order to obtain an extensively growing culture, the resultant mycelium suspension was used to inoculate $(1 \mathrm{~mL} / \mathrm{flask})$ a total of 300 flasks of $500 \mathrm{~mL}$ containing $100 \mathrm{~mL}$ of the same medium that were incubated under the same conditions for 7 days [18].

\section{Extraction and isolation}

After the incubation period, the harvested broth of C. trifolii $(30 \mathrm{~L})$ was separated by vacuum filtration with filter paper (Whatman No. 42). Both the biomass and culture broth were dried by lyophilization (Freeze dryer 5 , Labconco) at $-40{ }^{\circ} \mathrm{C}$ and $5 \mathrm{mi}-$ crons $\mathrm{Hg}$ vacuum. Then they were extracted with methanol:chloroform (1:1). The extracts were concentrated to dryness under reduced pressure to give a crude extract. This residue was purified via column chromatography, using silica gel (Merck, $0.040-0.063 \mathrm{~mm}$ ). The column was eluted with hexane-ethyl acetate in gradient. TLC silica gel plates (Merck, $60 \mathrm{GF}_{254}$, $0.2 \mathrm{~mm}$ thickness) staining with iodine vapor and phosphomolybdic acid were employed and screened under UV light.

\section{Structural characterization}

Ergosterol. From the fractions eluted with $n$-Hx:AcOEt (95:5), $8.0 \mathrm{mg}$ of a solid white crystalline compound, $\mathrm{mp} 166-168{ }^{\circ} \mathrm{C}$ and Rf: 0.75 [TLC, $n$-Hx:AcOEt (9:1), silica gel], was obtained and identified as compound $\mathbf{1}$.

Ergosterol peroxide. From the fractions eluted with $n$-Hx:AcOEt (7:3), $6.4 \mathrm{mg}$ of a yellowish white crystalline solid, mp $166-167^{\circ} \mathrm{C}$ and Rf: 0.30 [TLC, $n$-Hx:AcOEt (8:2), silica gel], was obtained and identified as compound $\mathbf{2}$.

Cerevisterol. From the fractions eluted with $n$-Hx:AcOEt (1:1), $6 \mathrm{mg}$ of a white crystalline solid, $\mathrm{mp} 205-208^{\circ} \mathrm{C}$ and Rf: 0.19 [TLC, $n$-Hx:AcOEt (1:1), silica gel], was obtained and identified as compound 3 .

Brefeldin-A. From the fractions eluted with $n$-Hx:AcOEt (1:1), $4 \mathrm{mg}$ of a clear crystalline solid, $\mathrm{mp} 203-204^{\circ} \mathrm{C}$ and Rf: 0.22 [TLC, AcOEt, silica gel], was obtained and identified as compound 4.

\section{Acknowledgments}

Special thanks to Conacyt for the financial support throughout the Project 181820 and for the scholarship number 308291 to 
Alan Couttolenc, Virgilio Arenas-Fuentes and Miguel Ángel Lozano-Aburto from the Instituto de Ciencias Marinas y Ecología, Universidad Veracruzana, México. J.M.P. thanks the EU Research Potential (FP7-REGPOT-2012-CT2012-31637IMBRAIN) and the European Regional Development Fund (FEDER). G.B.P. thanks Fundación Caja Canarias for a postgraduate grant.

Finally, A. V. Shnyreva appreciates the support from Russian Science Funds, grant 14-50-00029 (strain identification and sequencing).

\section{References}

1. Bungi, T.; Ireland, C. Nat. Prod. Rep. 2004, 21, 143-163.

2. Trisuwan, K.; Rukachaisirikul, V.; Phongpaichit, S.; Preedanon, S.; Sakayaroj, J. Arch. Pharm. Res. 2011, 34, 709-714.

3. Miksicek, R.J. J. Steroid. Biochem. Mol. Biol. 1994, 49, 153-160.

4. Janin, Y.L. J. Med. Chem. 2005, 48, 7503-7512.

5. Jadulco, R.; Brauers, G.; Edrada, R.A.; Ebel, R.; Wray, V.; Sudarsono, S.; Proksch, P. (2002). J. Nat. Prod. 2002, 65, 730-733.

6. Teles, H.L.; Silva, G.H.; Castro-Gamboa, I.; Bolzani, V.S.; Pereira, J.O.; Costa-Neto, C.M.; Haddad, R.; Eberlin, M.N.; Young, M.C.M.; Araujó, A.R. Phytochemistry. 2005, 66, 2363-2367.

7. Greve, H.; Schupp, P.J.; Eguereva, E.; Kehraus, S.; Kelter, G.; Maier, A.; Fiebig, H.; König, G.M. Eur. J. Org. Chem. 2008, 30, 5085-5092.
8. Couttolenc, A.; Espinoza, C.; Fernández, J.J.; Norte, M., Plata, G.B.; Padrón, J.M.; Shnyreva, A., Trigos, Á. Pharm. Biol. 2015, in press, doi:10.3109/13880209.2015.1081254.

9. Suárez-Medellín, J.; Mendoza, G.; Espinoza, C.; Suárez-Quiroz, M.L.; Trigos, Á. Lat. Am. J. Pharm. 2014, 33, 224-230.

10. Mendoza, G.; Suárez-Medellín, J.; Espinoza, C.; Ramos-Ligonio, A.; Fernández, J.J.; Norte, M.; Trigos, Á. Int. J. Med. Mushrooms. 2015, 17, 501-509.

11. Glaser, R.; Shiftan, D.; Froimowitz, M. Magn. Reson. Chem. 2000, 38, 274-280.

12. Nebenführ, A.; Ritzenhalter, C.; Robinson, D.G. Plant Physiol. 2002, 130, 1102-1108.

13. Zheng, C.J.; Xu, L.L.; Li Y.Y.; Han, T.; Zhang, Q.Y.; Ming, Q.L.; Rahman, K.; Qin, L.P. Cytotoxic metabolites from the cultures of endophytic fungus from Panax ginseng. Appl. Microbiol. Biotechnol. 2013, 97, 7617-7625.

14. Wang, G.; Li, Q.; Zhu, P. Antonie Van Leeuwenhoek. 2008, 93, 163-174.

15. Barnett, H.L.; Hunter, B.B. Illustrated Genera of Imperfect Fungi. American Phytopathological Society Press, Ed. St. Paul, Minnesota, 1998.

16. Watanabe, T. Pictorial Atlas of Soil and Seed Fungi: Morphologies of Cultured Fungi and Key to Species. $2^{\text {nd }}$ edition. CRC Press ED. Boca Raton, Florida, 2002.

17. Skehan, P.; Storeng, R.; Scudiero, D.; Monks, A.; McMahon, J.; Vistica, D.; Warren, J.T.; Bokesch, H.; Kenney, S.; Boyd, M.R. J. Natl. Cancer. Inst. 1990, 82, 1107-1112.

18. Trigos, Á.; Mendoza, G.; Espinoza, C.; Salinas, A.; Fernández, J.J.; Norte, M. Phytochem. Lett. 2011, 4, 122-125. 